\title{
EDITORIAL
}

\section{Harmful Tax Competition}

\author{
Toshiaki Katsushima, Deloitte \& Touche Tohmatsu, Tokyo
}

Globalization and the technological revolution have created exciting opportunities and challenges for businesses and consumers. Similarly, globalization and the technological revolution have created challenges for tax authorities throughout the world. One of the challenges brought about by these changes which is a hot issue for industrialized countries is the increased opportunities for financial crimes, such as money laundering, and the increased use and proliferation of tax havens and preferential tax regimes. With respect to tax havens and certain preferential tax regimes, many governments believe these are harmful, if not destructive, tax practices which erode national tax bases, distort trade and investment, shift the tax burden to labour and even harm global competition among businesses. This is commonly referred to as harmful tax competition. How governments and their respective tax authorities respond to harmful tax competition could have significant implications to the global tax burden of multinational companies and possibly to the global structure of these companies.

The European Union (EU) was the first governmental body to formulate measures against harmful tax practice or harmful tax competition. The EU released its Code of Conduct for Business Taxation in December 1997. The goal of the EU's Code of Conduct is to eliminate harmful tax competition among EU Member States.

The EU Code of Conduct provides five broad criteria for determining when a low or preferential tax regime should be considered harmful. In addition, under the Code of Conduct, EU Member States have made a commitment not to introduce new tax measures considered to be harmful and to review and abolish existing laws and practices which are considered harmful under the Code of Conduct for Business Taxation. A target timetable of January 2003 for the elimination of harmful tax competition was set.

The OECD, four months later in April 1998, launched its attack on tax havens and harmful preferential tax regimes when it issued Harmful Tax Competition: An Emerging Global Issue (OECD Report). (It is interesting to note that the OECD Report was approved by all member countries except for Switzerland and Luxembourg.) The OECD Report focuses only on geographically mobile activities (financial and other service activities).

Additionally, unlike the EU, the OECD did not limit its attack on harmful tax competition existing in OECD member countries but included non-OECD member countries. The OECD by including nonOECD countries in the attack on harmful tax competition, as defined by it, recognizes that the success of its attack depends on non-member countries joining them in the attack on harmful tax competition.

According to the OECD Report, it does not attempt to abolish tax regimes which have a zero or low tax rate or contains preferential rules or practices but tax regimes with no or low tax rates which possess harmful factors. Thus, the OECD Report sets forth criteria to be used in identifying harmful tax practices. This criteria does not provide a detailed and precise definition of tax havens and harmful preferential tax regimes. Instead, it provides relevant factors such as no or low taxes, lack of effective exchange of information and lack of transparency. In the case of tax havens, a no substantial activities factor is included in the relevant criteria. While for preferential tax regimes a criteria regarding the application of particular provisions are restricted to transactions inside a 'ring fence' or provisions which do not apply to transactions inside a 'ring fence' are added to the aforementioned determining criteria.

The recommendations of the OECD Report fall into three categories: unilateral measures through domestic legislation, bilateral measures through tax treaties, and multilateral measures. I would like to highlight some of the domestic legislation recommendations. These recommendations include adoption of controlled foreign company (CFC) legislation, foreign investment fund (FIF) legislation and foreign information reporting rules. Also, adherence to the OECD Transfer Pricing Guidelines is recommended.

Moreover, the OECD report establishes a Forum on Harmful Tax Practices. The Forum will evaluate existing and proposed regimes, analyze the efficacy of measures to counteract harmful tax practices, monitor implementation of the guidelines and the recommendations and to compile a list of tax havens.

The Forum is presently at work with respect to identifying tax havens and harmful preferential tax regimes. The Forum is to provide its list of tax havens and harmful preferential tax regimes in November 1999. I wait with interest to see the list of countries with harmful tax practices. I am especially interested in how the Forum handles such countries as Belgium (coordination centres), Ireland (International Financial $\&$ Service Centre and now a 12.5 per cent rate for all 
profits), and the Netherlands (Distribution Centre, finance companies and their rulings practice).

Additionally, the OECD Report, similar to the EU Code of Conduct, sets forth guidelines concerning not adopting any new harmful tax practices, reviewing existing laws and practices to identify existing harmful tax practices, and abolishing the harmful tax practices by 2003 .

The business community was fairly quiet in its reaction to the EU's and OECD's reports on harmful tax competition until this past June when the Business and Industry Advisory Committee to the OECD (BIAC) issued its highly critical written response to the OECD Report. I do not plan to give a detailed summary of the BIAC's written response but will touch on certain comments.

The BIAC took off its gloves in the first two sentences of its written response:

'The multinational business community speaks with a single voice when it puts forth the view that tax competition, generally is a healthy phenomenon, from the points of view of both government and business. We believe that it is not erroneous to state that it is unwarranted taxation by governments, rather than competition among them in the tax area, that is stifling to economic and business development.'

The BIAC, however, agrees with the OECD in rejecting 'fraudulent behaviour' or any tax regimes which 'promote and facilitate fraudulent practices'. BIAC goes on to state that the OECD's efforts to combat tax fraud are too broad in that they 'attack every nation that has a favourable tax climate which attracts business from other states'.

Further, the BIAC appropriately indicates that the OECD Report gives the impression that taxation is the major factor taken into account by MNCs in structuring their business activities. The BIAC lists other activities businesses consider in choosing a location, such as availability of trained labour and related labour costs, infrastructure and proximity to suppliers and markets.

The BIAC also questions the OECD Report's implicit notion that active and viable financial services companies are 'inherently more mobile in their geographical sites than are other commercial and industrial firms'. Based upon my experience, I agree with the BIAC's position on this issue. MNCs in the financial services industry take into consideration various factors, including tax, in deciding where to locate a business; although I will grant that capital for the financial service industry is more mobile than other industries. Of course, exceptions to this fact can be found but these exceptions should not taint legitimate businesses.

Also, the BIAC correctly points out that the OECD Report conveys the impression that the OECD is encouraging higher taxes. This is the impression I came away with after reading the OECD Report. Although the OECD officials have stated that the report does not attempt to harmonize tax rates, explicitly or implicitly, or call for any minimum level of taxation, I still have a concern that this initiative, if unchecked, over time could lead to putting the brakes on the long, continuing worldwide trend of lowering taxes at a minimum. A trend I believe overall has brought significant benefits to individuals, businesses and the global economy.

I share the BIAC's viewpoint that CFC and FIF legislation tends to be complex and generally creates compliance issues for taxpayers. Clearly, if the OECD harmful tax competition initiative results in continually increasing the compliance burden on taxpayers, especially the small to medium-size companies, I do not see how this will help correct distortions in market competition. If anything, it will put small to mediumsize companies at a disadvantage to large companies because the compliance costs will be too high. Although, as a practical matter, it probably will be very difficult to persuade governments not to enact such legislation. One question I have for governments in this regard is, assuming harmful tax competition is brought under control in the future, will they repeal $\mathrm{CFC}$ legislation?

Finally, the OECD Report contains many valid points including the need to prevent tax fraud and evasion, the need for transparency and the need for more exchange of information among others. However, the issues and concerns raised in the OECD are highly complex. The OECD Report in its entirety seems too blunt an instrument to address these complex issues. Accordingly, the OECD should revisit its Report and exercise prudence in going forward with its harmful tax competition initiative. Further, they should actively involve the business community in this process. 